\title{
A new species and new records of Cybaeus L. Koch, 1868 (Aranei: Cybaeidae) in the Maritime Province of Russia
}

\author{
Новый вид и новые находки пауков рода Cybaeus L. Koch, 1868 \\ (Aranei: Cybaeidae) в Приморском крае
}

\author{
Yuri M. Marusik ${ }^{1-3}$, Mikhail M. Omelko ${ }^{4-5}$ \\ Ю.М. Марусик ${ }^{1-3}$, М.М. Омелько ${ }^{4-5}$
}

\footnotetext{
${ }^{1}$ Institute for Biological Problems of the North, FEB RAS, Portovaya Str. 18, Magadan, Russia. E-mail: yurmar@mail.ru

${ }^{2}$ Department of Zoology \& Entomology, University of the Free State, Bloemfontein 9300, South Africa.

${ }^{3}$ Zoological Museum, Biodiversity Unit, University of Turku, FI-20014, Finland.

${ }^{4}$ Federal Scientific Center of East Asia Terrestrial Biodiversity, Far Eastern Branch, Russian Academy of Sciences, Vladivostok 690022, Russia. E-mail: omelkom@gmail.com

${ }^{5}$ Far Eastern Federal University, Laboratory of ecology and evolutionary biology of aquatic organisms (LEEBAO), School of Natural Sciences, Vladivostok 690091, Russia.

${ }^{1}$ Институт биологических проблем Севера, ДВО РАН, Портовая 18, Магадан 685000 Россия.

${ }^{4}$ Федеральный научный центр Биоразнообразия наземной биоты Восточной Азии ДВО РАН, Владивосток 690022, Россия.

5 Дальневосточный Федеральный Университет, Лаборатория экологии и эволюционной биологии водных организмов (ЛЭБВО), Школа Естественных Наук, Владивосток 690091, Россия.
}

KEY WORDS: Far East Asia, Primorsky Krai, Araneae.

КЛЮЧЕВЫЕ СЛОВА: Дальний Восток, Приморье, Araneae.

ABSTRACT. A survey of Cybaeidae in Far East Russia reveals three additional species: two species recently described from northeastern China, C. fushun Lin et Li, 2021 and C. huadian Lin et Li, 2021, and one species new to science, $C$. mikhailovi sp.n. $\left(\mathrm{O}^{7}+\right)$. Females of $C$. fushun and $C$. huadian are redescribed And the previously unknown male of $C$. fushun is described for the first time.

How to cite this paper: Marusik Yu.M., Omelko M.M. 2021. A new species and new records of Cybaeus L. Koch, 1868 (Aranei: Cybaeidae) in the Maritime Province of Russia // Arthropoda Selecta. Vol.30. No.2. P.216-220. doi: 10.15298/arthsel.30.2.08

РЕЗЮМЕ. В результате исследования пауков, собранных в Приморском крае, были обнаружены 3 новых для региона вида пауков рода Cybaeus. Из них два вида недавно описаны из Северо-восточного Китая C. fushun Lin et Li, 2021 и $C$. huadian Lin et Li, 2021, а один вид C. mikhailovi sp.n. (○) новый для науки. Самки C. fushun и C. huadian переописаны. Впервые описан ранее неизвестный самец $C$. fushun.

\section{Introduction}

Cybaeidae is a relatively small family with only 290 named species distributed in Holarctic and Neotropics [WSC, 2021]. Cybaeus L. Koch, 1868 is a large genus encompassing 185 species, or more than $60 \%$ species of the whole family. This genus has exclusively
Holarctic distribution, with the exception of C. signatus Keyserling, 1881 from Peru known only on the basis of females, and is most probably misplaced. The highest species diversity of the genus occurs in Japan with 92 named species [WSC, 2021]. Most of Cybaeus species have limited distribution ranges.

The first Cybaeus species from Russia were reported in 1991 by Marusik \& Logunov [1991], who described three species, namely C. bam Marusik et Logunov, 1991, C. basarukini Marusik et Logunov, 1991 and C. kunashirensis Marusik et Logunov, 1991 from Sakhalin Area. More recently, two more species have been added to fauna of Russia, both collected from the Russian Far East: C. confrantis Oliger, 1994 (Maritime Province) [Oliger, 1994] and C. striatipes Bösenberg et Strand, 1906 (Sakhalin Area [Marusik, Crawford, 2006]).

While collecting material in Maritime Province or studying specimens deposited in museum collections, we recognised that there are more than one species of Cybaeus occurring in this region. Unfortunately, we were not able to identify most of these material except for those belonging to $C$. confrantis, which along with other new data are reported and described herein.

\section{Material and methods}

Specimens were photographed in dishes of different size with paraffin on the bottom (different size holes were made in the bottom to keep specimens in the right position), using an Olympus Camedia C-5050 camera attached to an Olym- 

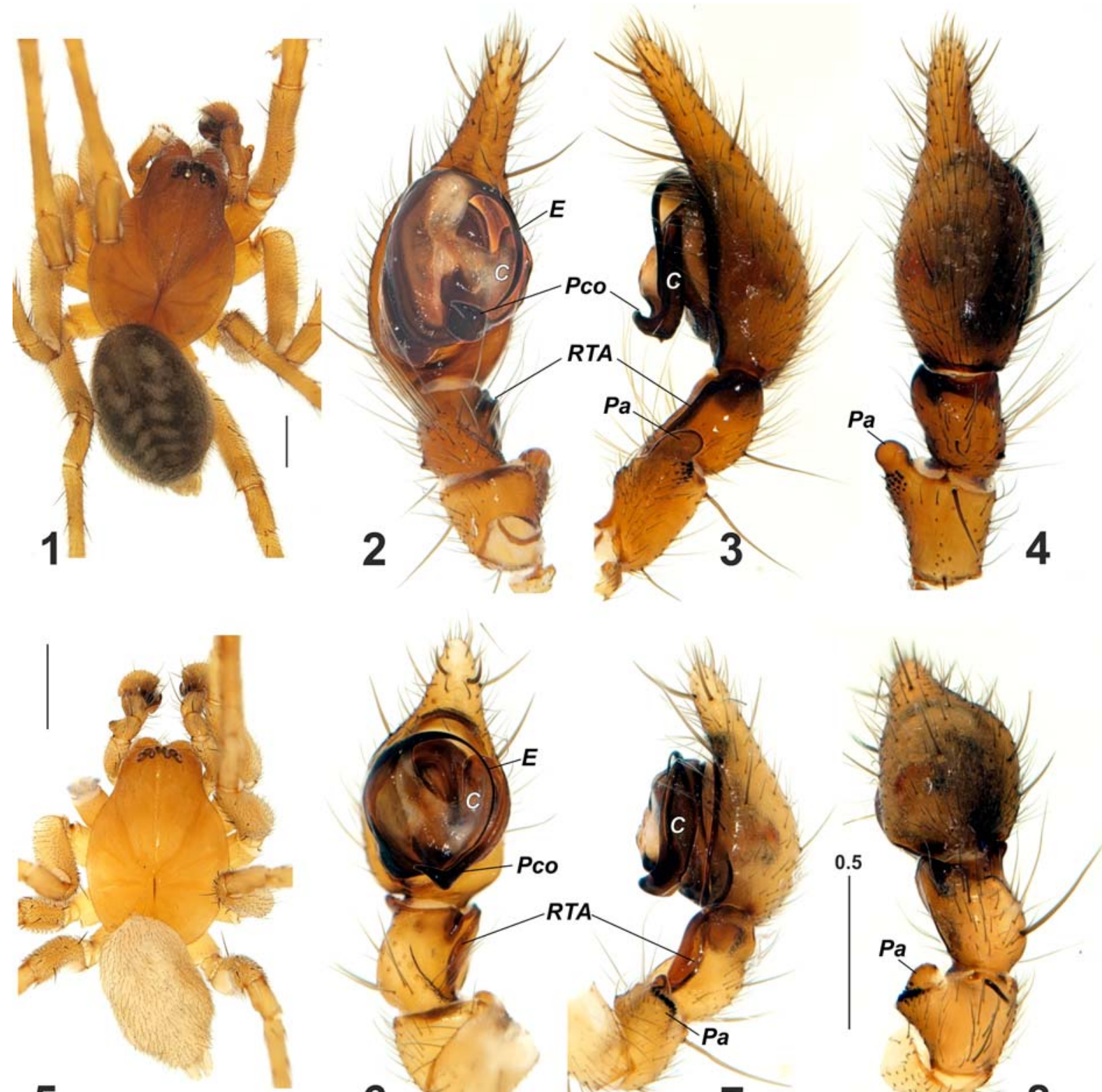

5
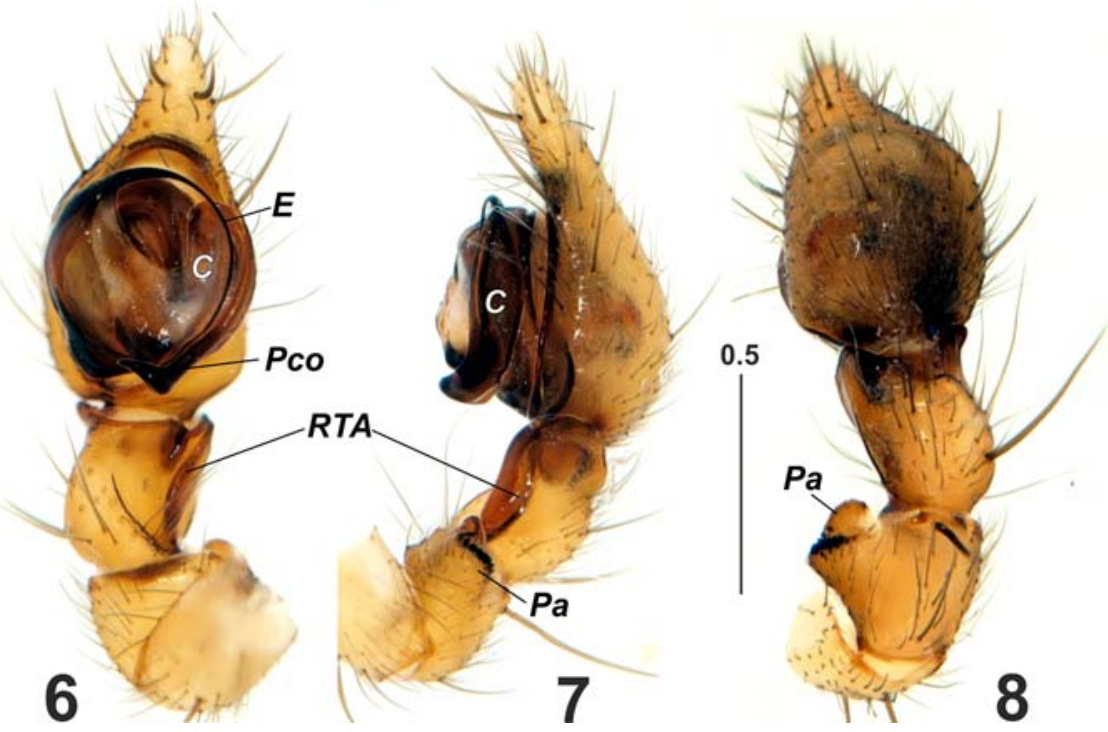

Figs 1-8. General appearance and palp of Cybaeus fushun (1-4) and C. mikhailovi sp.n. (5-8) males. 1, 5 - general appearance, dorsal; 2, 6- palp, ventral; 3, 7 - palp, retrolateral; 4, 8 - palp, dorsal. Scale: $1,5-1 \mathrm{~mm} ; 6-8-0.5 \mathrm{~mm}$. Abbreviations: $E-$ embolus, $\mathrm{C}$ - conductor, $\mathrm{Pa}$ - patellar apophysis, $\mathrm{Pco}-$ proximal arm of conductor, $R T A-$ retrolateral tibial apophysis.

Рис. 1-8. Внешний вид и пальпа самцов Cybaeus fushun (1-4) и C. mikhailovi sp.n. (5-8). 1, 5 - внешний вид; 2, 6 - пальпа, вентрально; 3, 7 - пальпа, ретролатерально; 4, 8 - дорзально. Масштаб: $1,5-1$ мм; 6-8 - 0,5 мм. Сокращения: $E-$ эмболюс, $P a$ - коленный отросток, $P c o$ - проксимальный вырост кондуктора, $R T A$ - ретролатеральный отросток голени.

pus SZX12 stereomicroscope at the Zoological Museum of University of Turku. The images have been montaged using "CombineZP" image stacking software.

All measurements are given in millimeters. In most of cases, the smallest and the largest specimens of each sex were measured. Description of somatic characters (excepts for size) are given briefly, because they have little taxonomic importance in distinguishing sibling species. $\mathrm{KOH}$.

Soft tissues of epigyne were dissolved using boiling
Most of the material treated here were collected during the Finnish-Russian expedition to Maritime Province in 1998, by Seppo Koponen and Yuri Marusik, and also many specimens we got from Yuri Sundukov.

Depositories: ZMMU - Zoological Museum, Moscow State University; ZMUT — Zoological Museum, University of Turku.

Abbreviations used in the text and figure plates: $A g-$ accessory gland, $\mathrm{C}$ - conductor, $\mathrm{Cd}$ - copulatory duct, $\mathrm{Co}$ copulatory opening, $E-$ embolus, $F d-$ fertilization duct, 

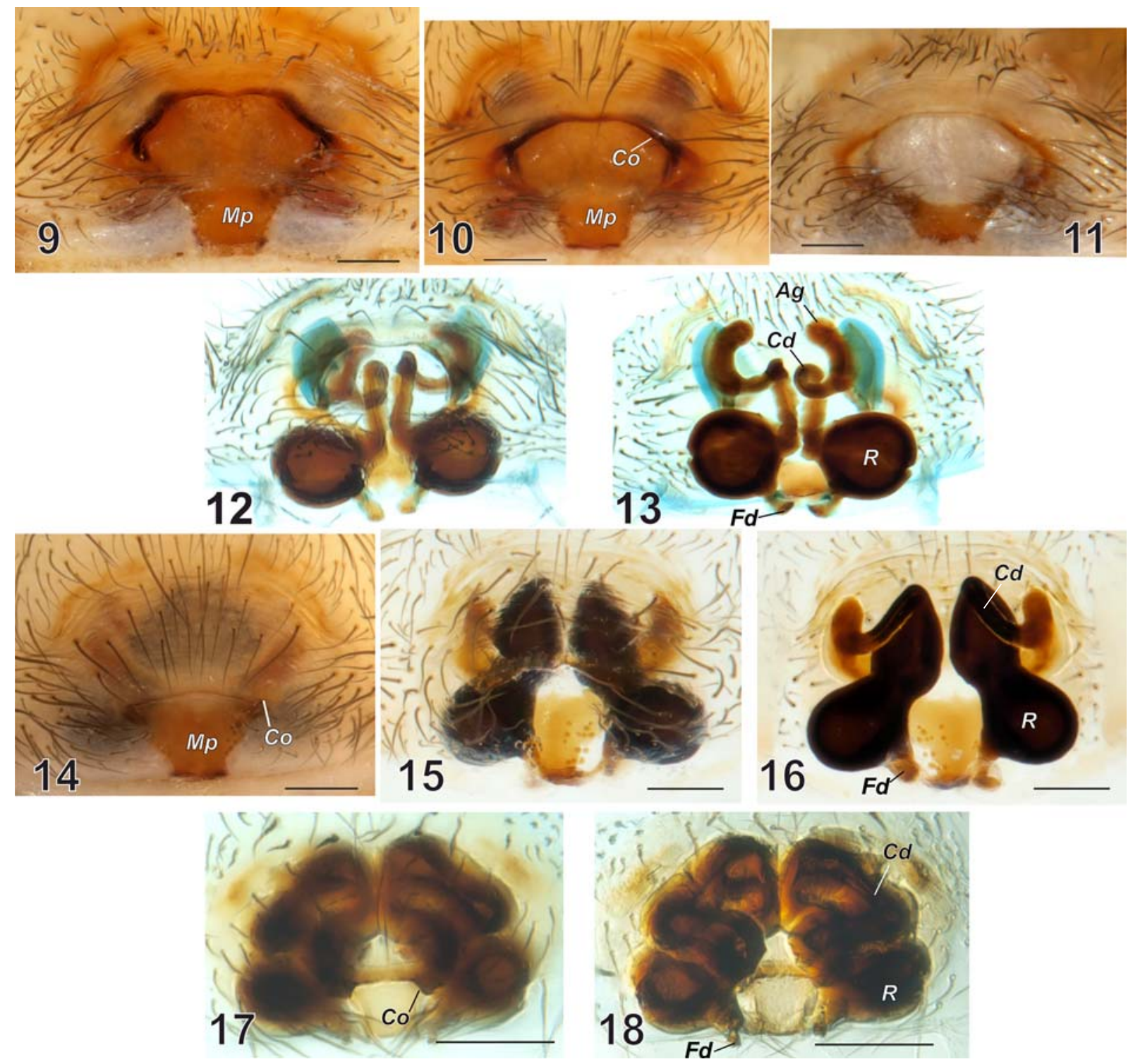

Figs 9-18. Epigyne of Cybaeus fushun (9-13), C. huadian (14-16) and C. mikhailovi sp.n. (17, 18). 9-11, 14 - ventral, intact; 12, 15, 17 - ventral, macerated; 13, 16, 18 - dorsal, macerated. Scale $=0.2 \mathrm{~mm}$. Abbreviations: $\mathrm{Ag}$ - accessory gland, $\mathrm{Cd}$ - copulatory duct, $C o$ - copulatory opening, $F d$ - fertilization duct, $M p$ - median plate, $R$ - receptacle.

Рис. 9-18. Эпигина Cybaeus fushun (9-13), C. huadian (14-16) и C. mikhailovi sp.n. (17-18). 9-11, 14 - вентрально, интактная; $12,15,17$ - вентрально, мацерированная; $13,16,18$ - дорзально, мацерированная. Масштаб: 0,2 мм. $A g$ - дополнительная железа, $C d$ - копулятивный канал, $C o$ - копулятивное отверстие, $F d$ - оплодотворительный канал, $R$ - рецептакула.

$M p$ - median plate, $P a$ - patellar apophysis, $P c o$ - proximal arm of conductor, $R T A$ - retrolateral tibial apophysis, $R$ - receptacle.

\section{Species survey}

Cybaeus fushun Lin et Li, 2021

Figs 1-4, 9-13, 19.

Cybaeus fushun Lin et Li, 2021 in Lin et al., 2021: 105, f. $15 \mathrm{~A}-\mathrm{B}, 17 \mathrm{~A}-\mathrm{B}(+)$.

MATERIAL EXAMINED: RUSSIA, Maritime Prov., south

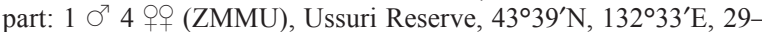
31.07.1998 (S. Koponen \& Yu.M. Marusik); $20^{7} \sigma^{7} 1$ ( (ZMMU),
Ussuriysky Reserve, Komarovo-Zapovednoe, $43^{\circ} 38^{\prime} 48^{\prime \prime} \mathrm{N}, 132^{\circ} 20^{\prime}$ 40"E, 22-29.07.1999 (Yu. Sundukov); 3 우 (ZMUT), Chuguyevka Field Station, ca $43^{\circ} 50^{\prime} \mathrm{N}, 134^{\circ} 15^{\prime} \mathrm{E}$, 31.07-5.08.1998 (S. Koponen); $2 \mathrm{O}^{7} \mathrm{O}^{7}$ (ZMMU), same locality and dates (Yu.M. Marusik); 2 오 (ZMMU), same locality, Summer 1991 (collector unknown);

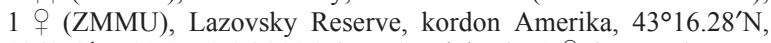
134으르, 30.05-2.06.2006 (Yu. Sundukov); 1 क (ZMMU), Lazo Reserve, Prosyolochnaya Bay, 30.8-1.09.2005 (Yu. Sundukov); 1 $0^{\top 1} 4$ 우 (ZMMU), Khasansky Dist., Gryaznaya River, $43^{\circ} 21^{\prime} 30^{\prime \prime} \mathrm{N}$, 131³6'E, 3-6.08.1999 (Yu. Sundukov); 1 q (ZMMU), Gornotayozhnoye Vil., 8.07.2007 (M.M. Omelko); 1 क (ZMMU), W of Khanka Lake, env. of Barabash-Levada Vil., $44^{\circ} 45.5^{\prime} \mathrm{N}, 131^{\circ} 27^{\prime} \mathrm{E}$, 18-19.07.1998 (Yu.M. Marusik); 1 \& (ZMMU), Medveditsa River, 24 km SE of Krounovka Vil., 10-14.08.1999 (Yu. Sundukov).

DIAGNOSIS. Males of this species differ from other large sized Cybaeus species by thin embolus $(E)$ and the 


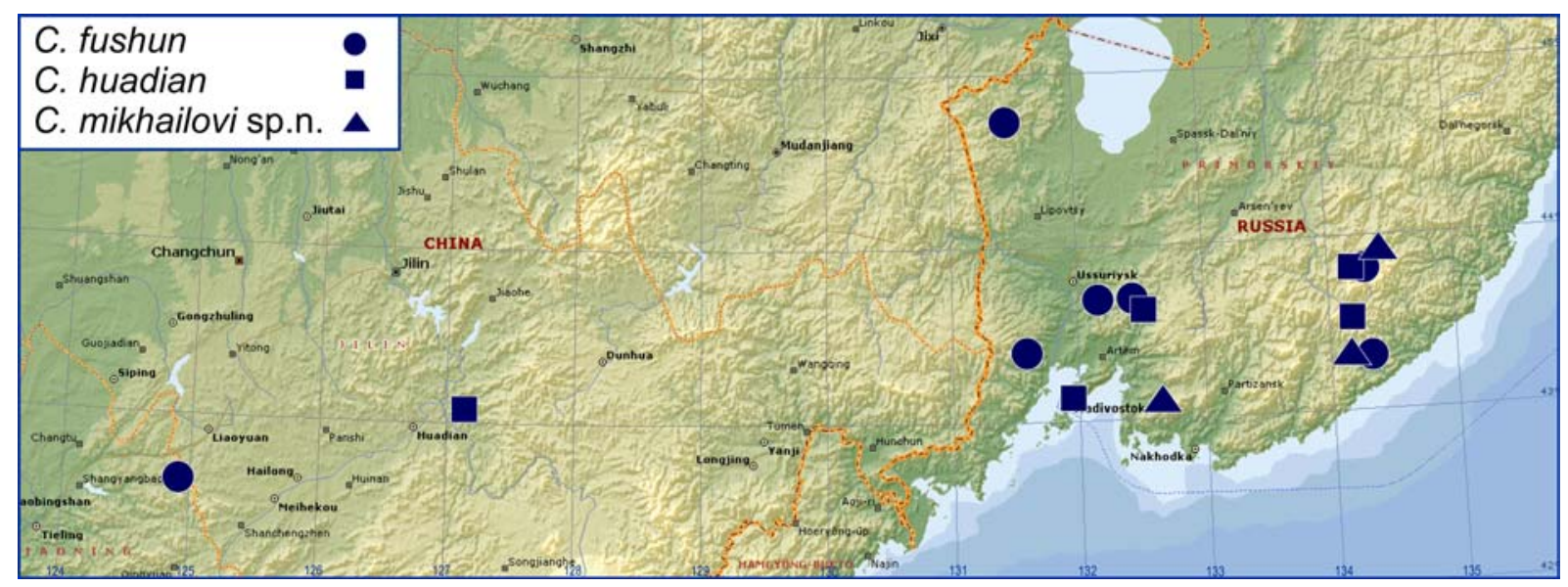

Fig. 19. Distribution records of C. fushun (circle), C. huadian (square) and C. mikhailovi sp.n. (triangle).

Рис. 19. Места находок C. fushun (кружок), C. huadian (квадрат) and C. mikhailovi sp.n. (треугольник).

rounded tip of patellar apophysis $(\mathrm{Pa})$. Females of $C$. fushun can be recognized by trapezoidal and sclerotized upper edge of the fovea and the unique shape of vulva with round spermathecae. The similar $C$. huadian has unsclerotized upper edge of fovea, larger median plate and differently shaped vulva. In addition, $C$. fushun is larger than $C$. huadian (carapace 4.83-4.9 vs. 3.83-4.27).

DESCRIPTION. Males. Total length 6.17-6.83. Carapace: 3.5-3.67 long, 2.5-2.67 wide. Carapace/femur I length ratio $0.91-0.93$. Leg I joints: femur 3.75-4.0, patella 1.17 1.3, tibia 3.75-4.67, metatarsus 3.83-4.67, tarsus 1.83-2.0. Abdomen with poorly visible pattern. Carapace with pattern consisting of a several paired spots. Legs with annulations, rings almost invisible. Male palp as in Figs 2-4. Patella subequal in length to tibia. Patellar apophysis $(\mathrm{Pa})$ with rounded tip. Cymbium long, its terminal part slightly shorter than bulb. Bulb longer than wide. Conductor $(C)$ with short anterior part originating at about 2 o'clock position, its proximal arm $(P c o)$ twisted at about 5 o'clock position. Free part of embolus $(E)$ originates at about 12 o'clock position and terminates at about 4 o'clock position.

Females. Total length 9.83-11.75. Carapace: 4.83-4.9 long, 3.17-3.25 wide. Carapace/femur I length ratio 1.181.2. Leg I joints: femur 4.0-4.08, patella $1.45-1.5$, tibia 4.17-4.25, metatarsus 3.58-3.67, tarsus 1.83-1.91. Coloration as in males, with more distinct leg annulations. Epigyne as in Figs 9-13. Fovea transverse, upper margins sclerotized more heavily than other parts, posterior part of fovea with median plate $(\mathrm{Mp})$.

DISTRIBUTION. Northeastern China (Liaoning Province) and Maritime Province of Russia (Fig. 19).

\section{Cybaeus huadian Lin et Li, 2021}

Figs 14-16, 19.

Cybaeus huadian Lin et Li, 2021 in Lin et al., 2021: 107, f. 16A-B, 17C-D ( + ).

MATERIAL EXAMINED: RUSSIA, Maritime Prov., south part: 6 우 (ZMMU), Chuguyevka Field Station, ca $43^{\circ} 50^{\prime} \mathrm{N}$ $134^{\circ} 15^{\prime} \mathrm{E}, 31.07-5.08 .1998$ (S. Koponen); 1 q (ZMUT), Oblach-

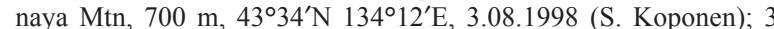
of (ZMMU), Ussuri Reserve, 4339' N 132³3'E, 29-31.07.1998 (S. Koponen); 1 ( (ZMMU), NW part of Vladivostok, catacombs, 21.08.1998 (Yu.M. Marusik).

DIAGNOSIS. See diagnosis for C. fushun.
DESCRIPTION. Females. Total length 8.83-9.33. Carapace: 3.83-4.27 long, wide 2.5-2.83. Carapace/femur I length ratio $1.15-1.2$. Leg I joints: femur 3.5-3.3, patella $1.17-1.33$, tibia 3.5-3.58, metatarsus $2.92-3.17$, tarsus $1.58-$ 1.67. Abdomen and carapace with distinct pattern. Legs annulated.

Epigyne as in Figs 14-16. Fovea transverse, upper margin not sclerotized, area above fovea dark due to translucent insemination ducts, down part of fovea with large median plate $(M p)$.

Male. Unknown.

DISTRIBUTION. Northeastern China (Jilin Province) and Maritime Province of Russia (Fig. 19).

\section{Cybaeus mikhailovi sp.n.}

Figs 5-8, 17-19.

TYPES: Holotype $\sigma^{7}$ (ZMMU), RUSSIA, Maritime Prov.,

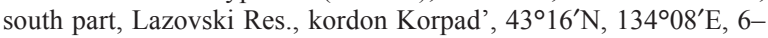
9.08.1998 (S. Koponen). Paratypes: RUSSIA, Maritime Prov., south part: 3 of (ZMUT), same data as for holotype; $1 \sigma^{7} 1$ ㅇ (ZMMU), same locality, 6-9.08.1998 (Yu.M. Marusik); 1 우 (ZMMU), Lazo Reserve, Syaogingou Gorge, Goral Mt., 18.08.1981 (T.I. Oliger); $4 \sigma^{\top} \sigma^{\top}$ (ZMMU), Lazo Reserve, kordon Amerika, 58.09.2005 (Yu. Sundukov); $2 \sigma^{7} \sigma^{7}$ (ZMMU), Lazo Reserve, Prosyolochnaya Bay, 30.8-1.09.2005 (Yu. Sundukov); $62 \sigma^{\top} \sigma^{7} 4$ 우

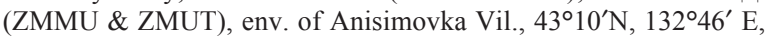
24-28.07.1998 (S. Koponen \& Yu.M. Marusik); 1 으는, Pravaya Izvilinka River, $43^{\circ} 55^{\prime} \mathrm{N}, 1^{\circ} 4^{\circ} 23^{\prime} \mathrm{E}, 1-2.08 .1998$ (Yu.M. Marusik)

ETYMOLOGY. This species is named in honour of our friend and colleague, Russian arachnologist K.G. Mikhailov (Moscow State University) on the occasion of his $60^{\text {th }}$ birthday.

DIAGNOSIS. Males of C. mikhailovi sp.n. are similar to C. yeongwolensis Lee, Yoo et Kim, 2021 and C. culter Lee, Yoo et Kim, 2021 known from South Korea, by small body size and lacling pattern. The new species can easily be diagnosed from both species by the shape of patellar apophysis (bifurcated with spines on its base $v s$. non-bifurcated with spines up to its tip). Females of the new species can be differentiated from known congeners by small size and the lack of abdominal pattern. Since the females of C. yeongwolensis and C. culter are not described, it is not known how the new species differs from them. 
DESCRIPTION. Males. Total length 3.83-4.67. Carapace: $2.0-2.3$ long, $1.17-1.5$ wide. Carapace/femur I length ratio 1.17-1.18. Leg I joints: femur 2.0-2.1, patella 0.2 0.42 , tibia $2.1-2.21$, metatarsus $1.67-1.7$, tarsus $1.33-1.35$. Uniformly coloured.

Male palp as in Figs 6-8. Patella with undivided apophysis rounded on tip. Tibia short, width almost equal to length. Cymbium long, its tip 1.5 times shorter than bulbus. Bulb as long as wide. Conductor with short upper arm terminating at ca. 1 o'clock position, and straight proximal arm $(\mathrm{PCO})$ bent at right angle at 5:30 o'clock position. Embolus $(E)$ filamentous, originates at ca. 11 o'clock position and terminating at about 5 o'clock position (making course at about $180^{\circ}$ ).

Females. Total length 4.17-5.33. Carapace: 1.83-1.9 long, $1.25-1.33$ wide. Carapace/femur I length ratio 0.95 0.98 . Leg I joints: femur $1.85-2.0$, patella $0.67-0.69$, tibia 1.55-1.6, metatarsus $1.30-1.33$, tarsus $0.85-0.90$. Coloration as in males.

Epigyne as in Figs 17-18; wider than long, with fovea as wide as long; copulatory ducts $(C d)$ broad, almost as wide as receptacle diameter.

DISTRIBUTION. Currently known only from southern parts of the Maritime Province in eastern Russia (Fig. 19).
Acknowledgements. We thank Alexander A. Fomichev (Barnaul, Russia) and Seppo Koponen (Turku, Finland) for the reviewing of our manuscript. English of the final draft was kindly checked and corrected by Alireza Zamani (Turku, Finland).

\section{References}

Lin Y.J., Marusik Yu.M., Gao C.X., Xu H., Zhang X.Q., Wang Z.Y., Zhu W.H., Li S.Q. 2021. Twenty-three new spider species (Arachnida: Araneae) from Asia // Zoological Systematics. Vol.46. No.2. P.91-152.

Marusik Yu.M., Crawford R.L. 2006. [Spiders (Aranei) of Moneron Island] // Flora i fauna ostrova Moneron. Vladivostok: Dalnauka. P.171-195 [in Russian, with English summary].

Marusik Yu.M., Logunov D.V. 1991. [Spiders of the superfamily Amaurobioidea (Aranei) from Sakhalin and Kurily Islands] // Zoologicheskiy Zhurnal. Vol.70. No.9. P.87-94 [in Russian, with English summary].

Oliger T.I. 1994. A new species of the spider genus Cybaeus L. Koch, 1868, from the Petrov Is., Sea of Japan // Arthropoda Selecta. Vol.3. No.1-2. P.51-55.

WSC. 2021. World Spider Catalog. Version 22.0. Natural History Museum Bern, online at http://wsc.nmbe.ch, accessed on May 21, 2021.

Responsible editor S. Koponen 